\title{
Application of the polygon method to analyze the differentiation of the regions of the Volga federal district by the level of e-business development
}

\author{
Marina Bikeeva*, and Evgeniya Sysoeva \\ National Research Mordovia State University, Saransk, Russian Federation
}

\begin{abstract}
The materials of the article contain an integral assessment of the level of development of e-business on the example of the regions of the Volga Federal District (VFD). As a result of calculating the private and local ranks of the values of the selected criteria, fourteen polygons of the level of e-business development were built by the number of regions in the district. The results obtained make it possible to ascertain the existence of a high degree of heterogeneity of the VFD regions in terms of the level of e-business development. The leading regions include the Republic of Tatarstan, the Perm Territory, and the Nizhny Novgorod Region. The outsider regions - the Republic of Mari El, the Republic of Mordovia and the Kirov region - are characterized by a low share of organizations that used the capabilities of the Intranet and Extranet in their activities, the lack of special software tools for managing sales of goods (works, services), limited use of software, in particular, ERP-, CRM and SCMsystems.
\end{abstract}

\section{Introduction}

Currently, there is not a single sphere of human activity that has not undergone significant changes as a result of the massive introduction of information and communication technologies (ICT). Modern information technologies are creating a new environment for economic activity, contributing to the development of e-business. The active use of the latest advances in information technology leads to the spread of new forms and directions of organizing entrepreneurial activity, as well as a new information

\footnotetext{
* Corresponding author: mbikeeva@yandex.ru
} 
sector of the economy: electronic commerce, electronic portals of various services, exchanges, etc.

Electronic business is understood as any business activity using the unlimited possibilities of global information networks to transform internal and external relations in order to create profit. The ICT capabilities that are provided, including the Internet, allow for fast and comprehensive interaction between business representatives and all of its counterparties (buyers, suppliers). At the same time, it becomes possible to move part of the processes outside the business, to give access to them to clients, and, thus, to reduce the duration and cost of processes, to speed up customer feedback procedures.

The characteristic features of e-business include the following:

- it is a business based on the use of information technology;

- it is a business in which the exchange of information is carried out using information systems;

- it is a business that makes extensive use of the power of the Internet.

The transformation of forms and types of e-business can be traced through the stages of its development and implementation in modern society. The history of e-business development in Russia can be divided into several stages: origin, implementation of technological innovations, penetration, distribution and consolidation in the market (Fig. 1). Let us consider the features of each of them.

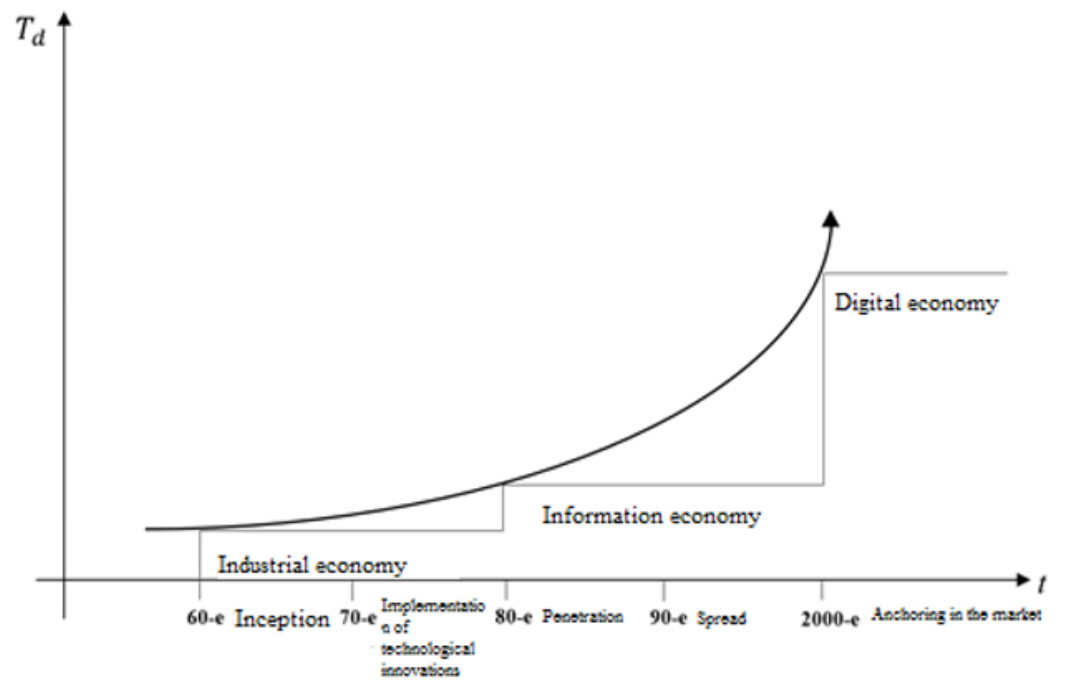

Fig. 1. Stages of e-business development in Russia.

The emergence of the basic principles of the information community covers the period of the $60 \mathrm{~s}-70 \mathrm{~s}$ of the XX century, which is characterized by the development of the theoretical foundations of a computer network and the formation of the basic rules of the information exchange standard. The features of the next stage, affecting 1970-1980. is the active development and implementation of technological innovation. The stage of penetration, which dates back to the 80 s and 90 s of the 20 th century, is characterized by the development and implementation of the Internet space, e-business, information automated systems for planning production processes at specific enterprises. And in the period from 1990 to 2000. the creation of global 
information automated environment begins, the emergence of electronic payment systems, the spread of electronic money, and Internet banking. The current stage of development of electronic business in Russia is characterized by the massive introduction of Internet technologies in all areas of business activity [2]. The goals and objectives of digital transformations in the Russian Federation are reflected in the Program "Digital Economy of the Russian Federation" [13] and other regulatory and legislative documents [9; 10;12], which should be implemented by the end of 2025 .

Thus, it can be assumed that the entire business sector will be involved in e-business in the near future. With the introduction of advanced ICT, ebusiness will acquire more and more new forms. In this regard, there is a need for a comprehensive statistical assessment of the level of development of electronic business in the territory.

\section{Study methodology}

An integrated approach based on simulation modeling can serve as an effective statistical toolkit for solving the problems of comparative analysis of the degree of business digitalization. One of the methods for assessing complex indicators is the graphical polygon (radar) method, which was originally used to comparatively characterize the competitiveness of enterprises. According to the authors of the article, this approach can be fully implemented to assess the level of development of electronic business in the regions of the VFD.

Based on the polygon (radar) method, the assessment of the level of development of electronic business in the regions of the VFD can be interpreted as a geometric figure. It can simultaneously serve as both a quantitative measure and an integral indicator. The stability of such a figure characterizes the real situation in the area of the level of business digitalization in a specific region of the VFD.

The principles of constructing a polygon (radar) for assessing the level of development of electronic business in the regions of the VFD:

- the circle is divided by radial rating scales into equal sectors according to the number of local criteria with the same weights;

- the value of the criterion increases with distance from the center of the circle;

- the scales on the radial straight lines are graded so that the values of the criteria are inside the evaluation circle;

- the criteria are assessed by ranking on an n-point scale (by the number of regions) [18, p.64].

As an information basis for the study, we used the data of Rosstat for 2019 in the context of the subjects of the VFD, as well as the results of monitoring the development of the information society in the Russian Federation [8].

\section{Study results}

ICT is one of the fastest growing industries in the world economy. A striking confirmation of this is the annual growth rate of the ICT industry, which exceeds the growth rate of traditional industries of the industrial economy, 
such as heavy engineering, oil production, and steel production [1]. Countries such as South Korea, China, India, Israel, by supporting and stimulating production in the field of ICT, were able to achieve a significant reduction in costs while increasing labor productivity, thereby making a qualitative breakthrough in their development $[6 ; 19]$. The widespread use of ICT helps to expand opportunities and improve the quality of coordination of business activities, allowing you to maximize the sales network with minimal financial costs and the absence of infrastructure barriers. The low cost of connecting to the Internet from virtually anywhere has made it possible to reduce geographical barriers, and the existence of various electronic payment systems has provided an opportunity to save time.

Undoubtedly, the development of e-business and e-commerce, as one of the most significant e-business processes, has impressive prospects on a global scale. According to the Statista research company, retail e-commerce sales worldwide amounted to USD $3.3 \operatorname{trln}$ [5]. Fig. 2 demonstrates an increasing trend in the development of e-commerce volumes, and forecast estimates until 2021 confirm the prospects for the development of global ebusiness.

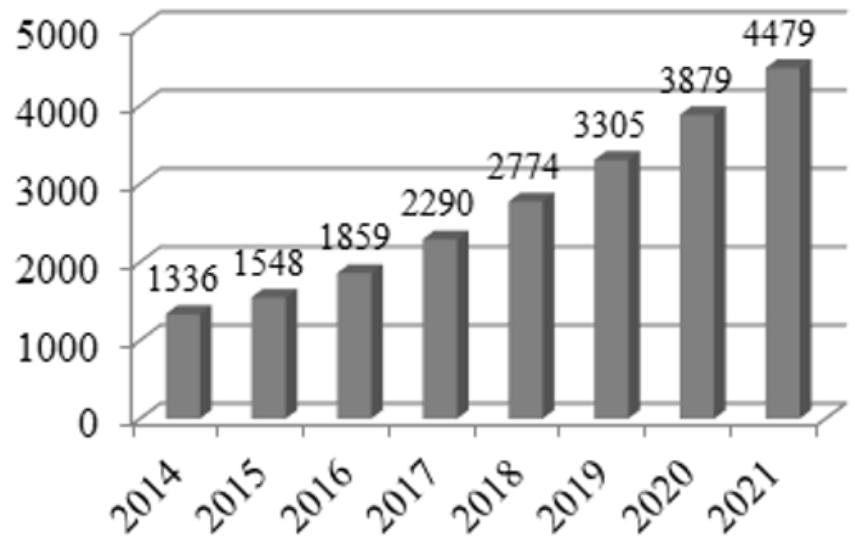

Fig. 2. Dynamics and forecast of the development of electronic commerce on a global scale.

Information technologies have become a solid basis for the development of e-business in Russia as well. According to the data for 2019, Russia ranks 45th (7.07 points) among the countries of the world in terms of the level of ICT development (ICT Development Index) [4]. Analysis of the dynamics of e-commerce volumes in Russia for 2011 - 2019 showed a positive development in this area (Fig. 3). 


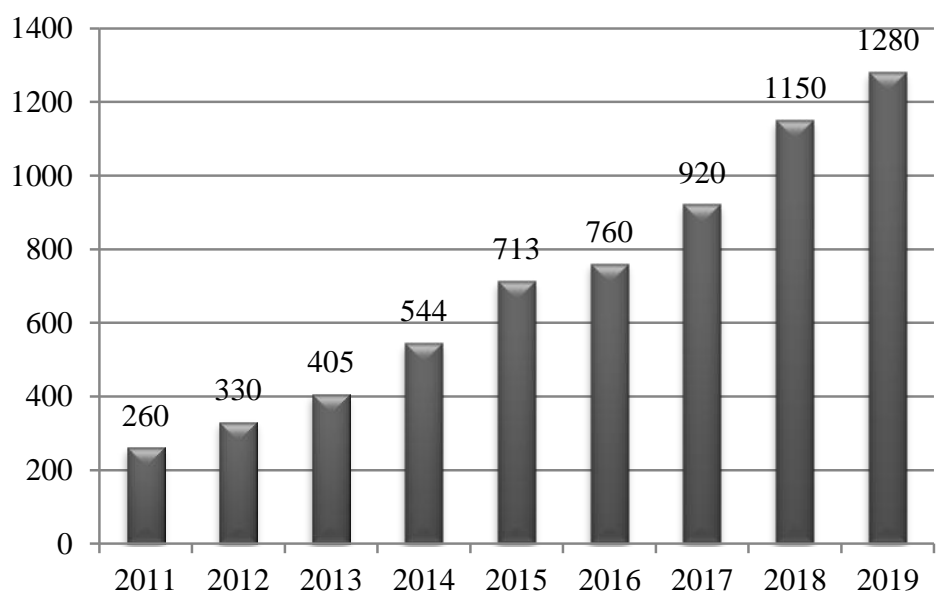

Fig. 3. Dynamics of development of e-commerce in Russia in 2011-2019.

The volume of the Russian e-commerce market at the end of 2019 amounted to RUR 1,280 bln, its share in the turnover of the entire Russian retail was $4.1 \%$. The share of cross-border trade in 2019 in the total volume of e-commerce amounted to almost a third, $28.5 \%$ or RUR 363 bln. According to analysts' forecasts, in the next 5 years, the volume of the Russian e-commerce market will grow to $8.5 \%$ of the total turnover and amount to RUR 2,780 bln [17].

According to the results of 2019, in the E-Commerce Index TOP-100, the Wildberries clothing and accessories store has a leading position, online sales of which amounted to RUR $111200 \mathrm{mln}$ [15]. The top three are the electronics and technology stores M.Video (RUR 52,800 mln) and Citilink (RUR 73,200 mln). The top five included the OZON department store (RUR $41,770 \mathrm{mln}$ ) and the DNS electronics and equipment store (RUR 38,810 $\mathrm{mln}$ ), showing $73 \%$ and $83 \%$ sales growth, respectively (Fig. 4).

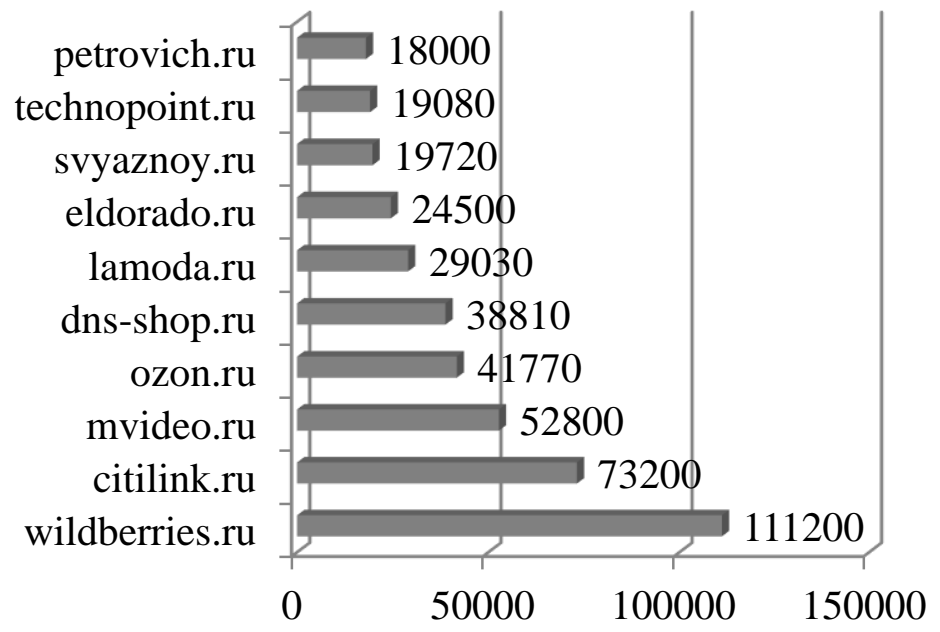

Fig. 4. TOP-10 largest representatives of e-commerce in Russia in 2019. 
To determine the degree of business digitalization, 16 local criteria were used, the list of which is presented in Table 1.

Table 1. List of local criteria for assessing the level of development of electronic business.

\begin{tabular}{|c|c|}
\hline $\begin{array}{l}\text { Item } \\
\text { No. }\end{array}$ & Criteria description \\
\hline $\mathrm{X} 1$ & $\begin{array}{l}\text { share of organizations using personal computers in the total number } \\
\text { of surveyed organizations }\end{array}$ \\
\hline $\mathrm{X} 2$ & $\begin{array}{l}\text { share of organizations using the Intranet in the total number of } \\
\text { surveyed organizations }\end{array}$ \\
\hline $\mathrm{X} 3$ & $\begin{array}{l}\text { share of organizations using the Extranet in the total number of } \\
\text { organizations surveyed }\end{array}$ \\
\hline $\mathrm{X} 4$ & $\begin{array}{l}\text { share of organizations using the Internet in the total number of } \\
\text { surveyed organizations }\end{array}$ \\
\hline $\mathrm{X} 5$ & $\begin{array}{l}\text { the number of personal computers with access to the Internet, per } \\
100 \text { employees of organizations }\end{array}$ \\
\hline $\mathrm{X} 6$ & $\begin{array}{l}\text { proportion of organizations with a website in the total number of } \\
\text { organizations surveyed }\end{array}$ \\
\hline $\mathrm{X} 7$ & $\begin{array}{l}\text { proportion of organizations using email in the total number of } \\
\text { surveyed organizations }\end{array}$ \\
\hline $\mathrm{X} 8$ & $\begin{array}{l}\text { the share of organizations that had special software tools for } \\
\text { managing the procurement of goods (works, services), in the total } \\
\text { number of surveyed organizations }\end{array}$ \\
\hline $\mathrm{X} 9$ & $\begin{array}{l}\text { the share of organizations that had special software tools for } \\
\text { managing sales of goods (works, services), in the total number of } \\
\text { surveyed organizations }\end{array}$ \\
\hline $\mathrm{X} 10$ & $\begin{array}{l}\text { share of organizations using ERP systems in the total number of } \\
\text { surveyed organizations }\end{array}$ \\
\hline $\mathrm{X} 11$ & $\begin{array}{l}\text { share of organizations using CRM systems in the total number of } \\
\text { surveyed organizations }\end{array}$ \\
\hline $\mathrm{X} 12$ & $\begin{array}{l}\text { share of organizations that used electronic document management } \\
\text { systems in the total number of surveyed organizations }\end{array}$ \\
\hline $\mathrm{X} 13$ & $\begin{array}{l}\text { share of organizations that used electronic data exchange between } \\
\text { their own and external information systems by exchange formats, in } \\
\text { the total number of surveyed organizations }\end{array}$ \\
\hline $\mathrm{X} 14$ & $\begin{array}{l}\text { share of organizations using SCM systems in the total number of } \\
\text { surveyed organizations }\end{array}$ \\
\hline $\mathrm{X} 15$ & $\begin{array}{l}\text { the share of organizations that placed orders for goods (work, } \\
\text { services) on the Internet, in the total number of surveyed } \\
\text { organizations }\end{array}$ \\
\hline $\mathrm{X} 16$ & $\begin{array}{l}\text { share of organizations that received orders for manufactured goods } \\
\text { (work, services) via the Internet, in the total number of surveyed } \\
\text { organizations }\end{array}$ \\
\hline
\end{tabular}

According to the values of the presented criteria, the ranking of the regions of the VFD was carried out. To obtain the ranks of the local criteria, the geometric means of the partial ranks are found. By connecting the rank values of local criteria with lines, polygons are obtained, each of which corresponds to one of the regions of the VFD. As a result of calculating the private and local ranks of the values of the corresponding criteria, fourteen 
polygons of the level of e-business development were built. Each radar in its limit value represents the radius of the circle corresponding to the most favorable value of the indicator.

Thus, a regional differentiation in the development of e-business has been identified. Among the leading regions are the Republic of Tatarstan, the Perm Territory and the Nizhny Novgorod Region. The outsider regions include the Republic of Mari El, the Republic of Mordovia, and the Kirov region (Fig. 5). The weaknesses of the outsider regions include the low share of organizations that used the capabilities of the Intranet, Extranet in their activities, the lack of special software tools for managing sales of goods (works, services), the limited use of software, in particular ERP-, CRM- and SCM- systems.
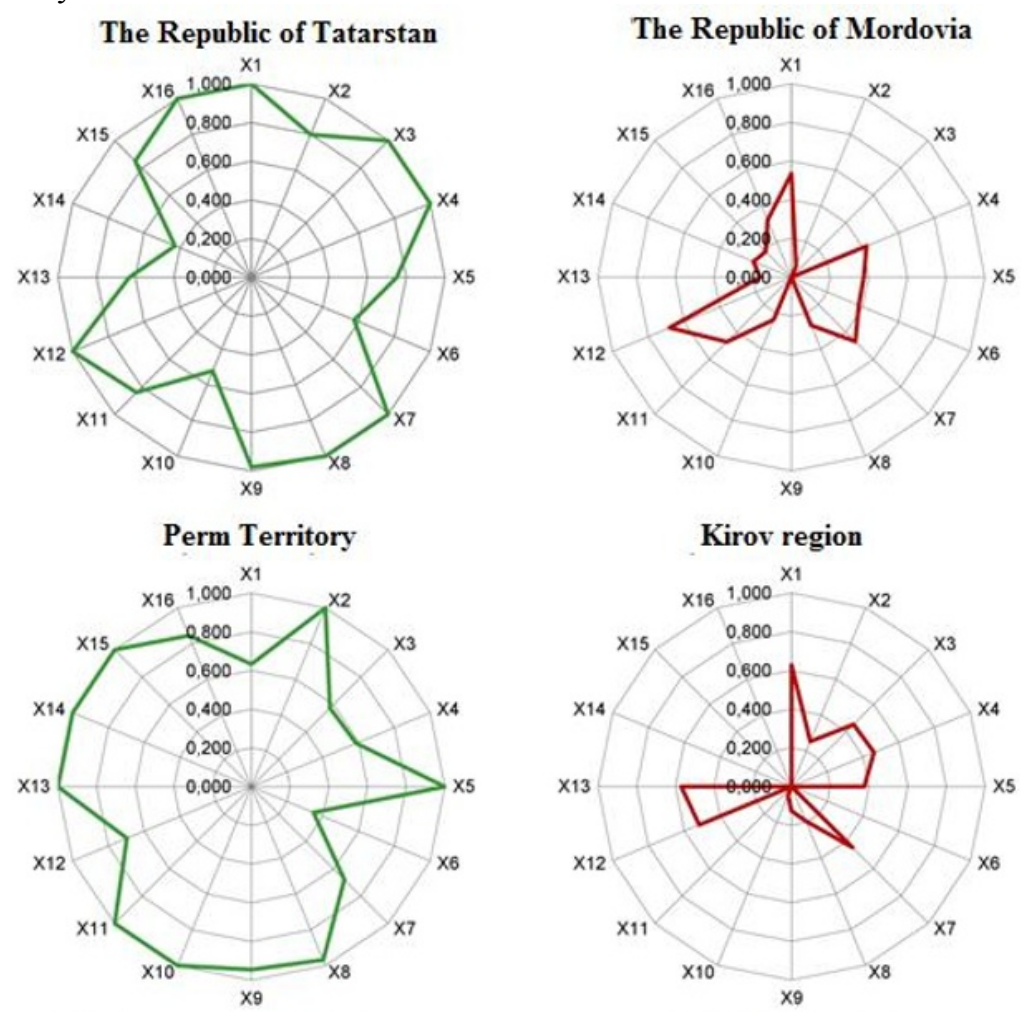

Nizhny Novgorod Region

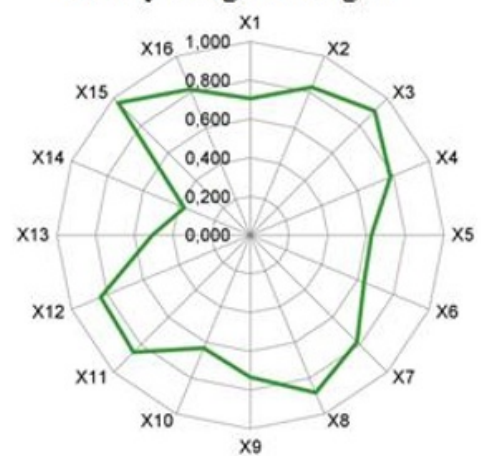

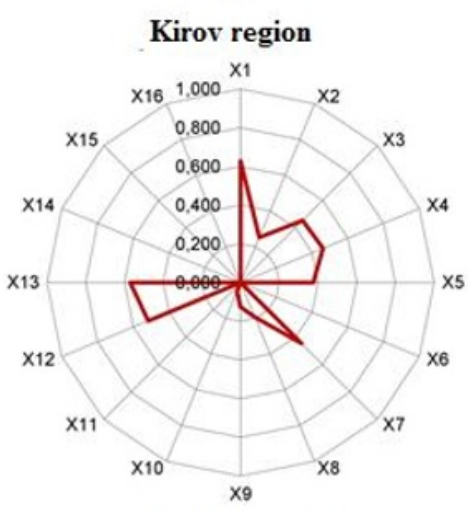

Mari El Republic

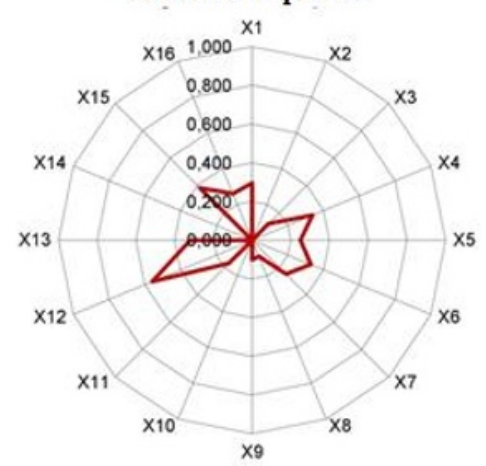

Fig. 5. Leading regions and outsider regions in terms of e-business development. 
The results obtained are confirmed by mathematical calculations. Were calculated generalizing indicators equal to the relative area of the polygon, built inside the evaluation circle according to the selected criteria. To calculate the e-business development index, the following formula was used:

$$
I_{i}=\frac{S_{i}}{S}
$$

where $\mathrm{Si}$ is the area of the polygon of the i-th region of the Volga Federal District;

$\mathrm{S}$ is the total area of the polygon of the "reference" region with the maximum possible rank values.

The indices of the development of electronic business in the regions of the VFD are given in Table 2.

Table 2. Indexes of e-business development in the regions of the VFD.

\begin{tabular}{|l|c|c|}
\hline $\begin{array}{c}\text { Territorial subject of the } \\
\text { federation }\end{array}$ & $\begin{array}{c}\text { Index of } \\
\text { development of } \\
\text { electronic business }\end{array}$ & Rank \\
\hline Republic of Bashkortostan & 0.5399 & 4 \\
\hline Republic of Mari El & 0.0480 & 14 \\
\hline Republic of Mordovia & 0.0928 & 12 \\
\hline Republic of Tatarstan & 0.7024 & 6 \\
\hline Udmurt Republic & 0.2671 & 5 \\
\hline Chuvash Republic & 0.3527 & 2 \\
\hline Perm Territory & 0.6877 & 13 \\
\hline Kirov region & 0.0667 & 3 \\
\hline Nizhny Novgorod Region & 0.5511 & 10 \\
\hline Orenburg region & 0.2597 & 11 \\
\hline Penza region & 0.1063 & 9 \\
\hline Samara region & 0.1062 & 8 \\
\hline Saratov region & 0.1175 & 0.1251 \\
\hline Ulyanov region & & \\
\hline
\end{tabular}

This method can be extended to assess the level of development of ebusiness to the scale of the entire country.

\section{Result discussion}

The development of innovative digital technologies in Russia and in the world is widely discussed within the framework of various discussion platforms. In particular, at the International Forum "Digital Future of the Global Economy" (January 31, 2020. Almaty), digitalization of trade processes between the EAEU member states has become one of the main topics. Tech Week Annual Conference (Moscow) is becoming a traditional place for discussion of issues on the implementation of innovative technologies in business, as well as the exchange of experience of leading Russian and world corporations in the field of e-business.

The growth in the number of participants in electronic business transactions is confirmed by the activity of scientific publications on electronic business.

In the works of most Russian scientists, an emphasis is placed on the theoretical foundations of the development of e-business, and the possibilities of its implementation into the practice of enterprises are considered. The 
research of A. Ivasenko and V. Alekseeva [3] touches upon the theoretical aspects of e-business, its essence and main directions of development. T. Margaryan and M. Perova [7] also give the concept of e-business, define its main functions and significance for the Russian economy, reveal the problems of running Internet business, its forms and tools, analyze functional models of the main sectors of e-commerce. A. Peteneva [11] considers the advantages and disadvantages of traditional and electronic commerce. The research materials of $\mathrm{M}$. Romantsov contain data on the types of e-business. The analysis of trends and promising areas of development of modern electronic business in Russia is performed in the study of V. Proskuryakov and O. Gorbunova [14], as well as the group of authors M.V. Melnik, T.V. Skryl, E.A. Gureeva, I.F. Vetrova, A.V. Vetrov [22]. It shows the dynamics of changes in indicators characterizing the development of e-commerce in Russia.

Studies by foreign scientists contain an extended approach to the development of e-business. Thus, the group of authors of M.M. Migdadi, M.K.S. Abu Zaid, O.S. Al-Hujran and A.M. Aloudat [23] defined the influence of the introduction of electronic business on the activity of the organization, key prerequisites of the successful introduction of business on the basis of organizational factors are described. Approach to assessment of the factors affecting the efficiency of development of electronic business is described in the article of S.X. Duan, H. Deng and F. Luo [21]. The use of statistical tools allowed B. Esmaeilpour Ghouchani, S. Jodaki, M. Joudaki, A. Balali and L. Rajabion to determine the range of factors for the development of e-business [20].

Thus, the diversity of the considered approaches to the development of ebusiness confirms the relevance and timeliness of the issues under consideration.

\section{Conclusion}

Information and communication technologies are becoming a powerful tool for the development of e-business. At the moment, the leaders in the global economic and political space are precisely those countries that have learned to determine the vector of development of information technologies, to use new opportunities for their application. Among the characteristic features of the current stage of e-business development is the massive introduction of Internet technologies and the transformation of traditional business methods. The introduction of advanced information and communication technologies contributes to the greater involvement of the business sector in e-business. According to the level of development of information and communication technologies (ICT Development Index), Russia ranks 45th among the countries of the world. For the period 2011-2019, the development of ebusiness in Russia has a positive trend. The volume of the Russian ecommerce market at the end of 2019 amounted to RUR 1,280 bln, or $4.1 \%$ of the total trade turnover. According to forecast calculations, by 2023 the volume of the Russian e-commerce market will grow to $8.5 \%$ of the total turnover and will amount to RUR 2,780 bln.

The results of assessing the level of development of electronic business of the subjects of the VFD allow us to state a high degree of heterogeneity of regions in terms of the investigated integral indicator. In this regard, 
measures are needed to smooth out the existing imbalances. Strategic approaches to increasing the level of development and efficiency of ebusiness should be the development of infrastructure and institutional support for the introduction of advanced digital technologies. At the same time, the implementation of the above-mentioned strategic approaches in a specific region should take into account their specificity and development features. Depending on this, both technological solutions that can be used for the development of information and communication infrastructure and measures to stimulate the introduction of specific digital technologies can vary.

\section{References}

1. E.YU. Dushkina, Evrazijskaya advokatura, 5(42), 20 (2019)

2. E.S. Epifanov, N.Z. Atarov, Voprosy regional'noj ekonomiki, 3, 106 (2016)

3. A.G. Ivasenko, V.E. Alekseeva, Sbornik statej pobeditelej VII Mezhdunarodnogo nauchno-prakticheskogo konkursa «Luchshaya nauchnaya stat'ya», 84 (2017)

4. G.I. Abdrahmanova, K.O. Vishnevskij, L.M. Gohberg $i$ dr., Indikatory cifrovoj ekonomiki: 2019: statisticheskij sbornik (M.: NIU VSHE, 2019)

5. K.V. Korobejnikova, Materialy IV Mezhdunarodnoj nauchnoj konferencii «Doneckie chteniya 2019: obrazovanie, nauka, innovacii, kul'tura i vyzovy sovremennosti, 97 (2019)

6. G.G. Malahmaev, Vestnik Severo-Kavkazskogo federal'nogo universiteta, 5(74), 82 (2019)

7. T.K. Margaryan, M.V. Perova, Proizvodstvennyj menedzhment: teoriya, metodologiya, praktika, 3, 18 (2015)

8. Monitoring razvitiya informacionnogo obshchestva $\mathrm{v}$ Rossijskoj Federacii, http://www.gks.ru/

9. O Strategii razvitiya informacionnogo obshchestva v Rossijskoj Federacii na 2017-2030 gody. Ukaz Prezidenta Rossijskoj Federacii ot 09.05.2017 g. № 203, http://static.kremlin.ru/media/acts/files/0001201705100002.pdf

10. Pasport nacional'noj programmy «Cifrovaya ekonomika Rossijskoj Federacii» (utverzhden prezidiumom Soveta pri Prezidente Rossijskoj Federacii po strategicheskomu razvitiyu i nacional'nym proektam: protokol ot 24 sentyabrya 2018 g. № 16), http://static.government.ru/media/files/urKHm0gTPPnzJlaKw3M5cNL o6gczMkPF.pdf

11. A.A. Peteneva, Sinergiya nauk, 6, 86 (2016)

12. Prognoz dolgosrochnogo social'no-ekonomicheskogo razvitiya Rossijskoj Federacii na period do 2030 goda (razrabotan Minekonomrazvitiya Rossii), http://www.consultant.ru/document/cons_doc_LAW_144190/

13. Programma «Cifrovaya ekonomika Rossijskoj Federacii» ot 28 iyulya 2017 g. № 1632-r., http://static.government.ru/media/files/9gFM4FHj4PsB79I5v7yLVuP gu4bvR7M0.pdf 
14. V.V. Proskuryakov, O.N. Gorbunova, Materialy III Mezhdunarodnoj nauchno-prakticheskoj konferencii «Informacionnye tekhnologii V ekonomike, biznese i upravlenii» (20 maya 2016 g., g. Tambov). 118 (2016)

15. Rejting TOP-100 krupnejshih internet-magazinov Rossii, http://datainsight.ru/top100/

16. M.S. Romancov, Social'no-ekonomicheskie yavleniya i processy, 12(4), 43 (2017)

17. Rynok elektronnoj torgovli v https://www.dp.ru/a/2019/03/13/Rinok_jelektronnoj_torgovl

18. R.A. Fathutdinov, Global'naya konkurentosposobnost'. $\mathrm{Na}$ stol sovremennomu rukovoditelyu: monografiya (M.: RIA Standarty i kachestvo, 2009)

19. A.P. CHernoivanov, Social'no-ekonomicheskie yavleniya i processy, 8(30), 155 (2011)

20. B. Esmaeilpour Ghouchani, S. Jodaki, M. Joudaki, A. Balali, L. Rajabion, VINE Journal of Information and Knowledge Management Systems, 50(1), 20 (2020)

21. S.X. Duan, H. Deng, F. Luo, Journal of Enterprise Information Management, 32(1), 60 (2019)

22. M.V. Melnik, T.V. Skryl, E.A. Gureeva, I.F. Vetrova, and A.V. Vetrov, Specifics of Decision Making in Modern Business Systems (Emerald Publishing Limited), 161 (2019)

23. M.M. Migdadi, M.K.S. Abu Zaid, O.S. Al-Hujran, A.M. Aloudat, Internet Research, 26(3), 661 (2016) 